Türker, M. S. (2019). Yabancı dil olarak Türkçe öğretenlerin eğitim teknolojisi standartları öz-yeterlik algılarının incelenmesi. Ana Dili Eğitimi Dergisi, 7(3), 574-596.

\begin{tabular}{c}
$\begin{array}{c}\text { Ana Dili Eğitimi Dergisi } \\
\text { Journal of Mother Tongue Education } \\
\text { www.anadiliegitimi.com }\end{array}$ \\
$\begin{array}{c}\text { Geliş/Received: } 05.04 .2019 \text { Kabul/Accepted:24.06.2019 } \\
\text { Araştirma Makalesi / Research Paper }\end{array}$ \\
\hline
\end{tabular}

\title{
Yabancı Dil Olarak Türkçe Öğretenlerin Eğitim Teknolojisi Standartları Öz-Yeterlik Algılarının İncelenmesi
}

\author{
Murat Sami TÜRKER*
}

\begin{abstract}
Öz
Eğitimde yaşanan yenilenme sürecinde en önemli rollerden biri de şüphesiz öğretmenlerin olacaktır. Davranış ve öğrenme biçimleri açısından önceki nesillere göre hayli farklılaşan dijital neslin öğrenme ihtiyaçlarına yanıt verebilecek, teknoloji becerileri üst düzey öğretmenler yetiştirmek yükseköğretim kurumlarının ihtiyaçlar listesinde yerini almıştır. Bu çalışmada, yabancı dil olarak Türkçe öğretenlerin eğitim teknolojisi standartları öz yeterlik düzeyleri yaş, cinsiyet, öğrenim durumu, öğretim kademesi, mezuniyet alanı ve mesleki deneyim değişkenleri açısından incelenmiştir. illk, orta ve yükseköğretim kurumlarında Türkçe öğreten 229 öğretmenin katılımıyla gerçekleştirilen çalışmanın sonuçları, öğretmenlerin eğitim teknolojisi standartları öz yeterlik algılarının yüksek düzeyde olduğunu ortaya koymuştur. Yaş değişkeni açısından değerlendirildiğinde, yabancı dil olarak Türkçe öğreten genç yaştaki öğretmenlerin öz yeterliklerinin orta yaş ve üzeri öğretmenlere göre daha yüksek olduğu, ancak cinsiyet, öğrenim durumu, öğretim kademesi, mezuniyet alanı ve mesleki deneyim değişkenleri açısından gruplar arasında anlamlı bir farklılaşma olmadığı saptanmıştır.
\end{abstract}

Anahtar Kelimeler: Eğitim teknolojisi, standartlar, öz yeterlik, ISTE, NETS

\section{An Investigation of Turkish as a Foreign Language Teachers' Self-Efficacy Beliefs Concerning Educational Technology Standards in Terms of Several Variables}

\begin{abstract}
One of the most important roles in the renewal process in education will undoubtedly be of teachers. In order to respond to the needs of the digital natives, who are mostly different from previous generations in terms of behavioral patterns and learning styles, higher education institutions need to train teachers equipped with high-level technology skills. In this study, educational technology standards self-efficacy levels of Turkish language teachers were examined in terms of age, gender, level of education, teaching level, department and professional experience. The participants were 229 Turkish language teachers in primary and secondary schools and higher education institutions. The results of the study showed that teachers' self-efficacy levels regarding educational technology standards were high. In terms of age variable, young teachers had higher self-efficacies compared to teachers of middle age and above, but there were no significant differences between the groups in terms of gender, level of education, teaching level, department and professional experience variables.
\end{abstract}

Keywords: Educational technology, standards, self-efficacy, ISTE, NETS

\footnotetext{
* Öğr. Gör. Dr., Anadolu Üniversitesi, Açıköğretim Fakültesi, Öğrenme Teknolojileri Ar-Ge Birimi, Eskişehir. e-posta: muratsturker@gmail.com ORCID: 0000-0002-2037-8508
} 


\section{Giriş}

Teknoloji uzun yıllar boyunca eğitimin vazgeçilmez bir parçası olmuştur. Eğitimde teknoloji uygulamalarının ilk örneklerinden olan mikro bilgisayarlardan bugün öğrencilerin elinde görmeye alışık olduğumuz tablet bilgisayarlara kadar zaman içerisinde teknoloji eğitimde daha geniş kullanım alanları bulmuştur (Younie ve Leask, 2013). Teknoloji desteği ile eğitim artık okul sınırlarını aşmış; evler, kütüphaneler, iş yerleri ve kafeler gibi sosyal ortamlar insanların ne zaman, nasıl ve ne öğrenmek istedikleri ile ilgili kendi kararlarını alabildikleri birer eğitim ortamı hâline gelmiştir (Collins ve Halverson, 2009).

Teknolojide yaşanan gelişmelere paralel olarak ortaya çıkan ve eğitim alanında da köklü değişimlerin habercisi olan bu reform sürecinde, öğretmenin öğrenme sürecinden tamamen soyutlanması veya teknolojinin öğretmenin yerini alması beklenemez (Cennamo, Ross ve Ertmer, 2010). Teknoloji, öğretimi gerçekleştiren değil öğrenmeyi destekleyen ve belirlenen amaçlara ulaşmak için yararlanılan araçlardır (Newby, Stepich, Lehman ve Russel, 2006). Bu açıdan bakıldığında, teknolojik yenilikler ışığında öğrencilerin ve öğretmenlerin farklılaşan rolleri ön plana çıkmaktadır (Cennamo ve diğerleri, 2010). Eğitimin en önemli aktörlerinden olan öğrenci ve öğretmenlerin değişen görev ve sorumluluklarını anlayabilmek için öğretmenlerin 21. yüzyıl öğrencilerinin karakteristik özelliklerinin farkında olmaları gerekir (Newby ve diğerleri, 2006). Öğrenme sürecine etkin katılmaları, bilgiyi kendilerine özgü yöntemlerle keşfetmeleri, bilgiyi geniş bir bağlamda diğer bilgi alanları ile ilişkilendirmeleri ve birçok beceriyi işe koşarak bilgiyi disiplinler arası bir yaklaşımla yapılandırmaları günümüz öğrencilerinin öne çıkan özelliklerinden bazılarıdır (Smaldino, Lowther ve Russell, 2014). Öğretmenler ise bugün yalnızca bilgiyi aktaran değil, bilgiye ulaşmada yol gösterici bir rehber olarak öğrenmeyi kolaylaştıran, öğrenme sürecinin etkin katılımcılarıdır (Newby ve diğerleri, 2006; Smaldino ve diğerleri, 2014; Younie ve Leask, 2013).

Her alanda olduğu gibi eğitim alanında da hızlı değişimlerin yaşandığı çağımızın özellikleri ve öğrenci ilgi ve gereksinimleri dikkate alındığında öğretmen yeterliklerinde de güncellemelere gidilmesi faydalı olabilir. Bu bağlamda, öğretmen yeterliklerinin sürekli güncellenmesini sağlayabilecek bir sistem geliştirilebilir, bu sistem kapsamında öğretmen adaylarına yönelik yükseköğretim programları ve öğretmenlere yönelik hizmet içi eğitim programları tasarlanabilir (Ilgaz ve Usluel, 2011). 21. yüzyılda görev yapan bir öğretmenin eğitim teknolojileri kullanımı konusunda bilgili ve uzman olması, onun teknolojik araçları tanıması ve kullanabilmesinden daha fazlasını gerektirir (Chen ve Thieleman, 2008). Usluel, Mumcu ve Demiraslan (2007) bilgi ve iletişim teknolojilerinin (BiT) öğrenme-öğretme sürecine entegrasyonuna ilişkin olarak yürüttükleri çalışmada, en sık karşılaşılan sorunlardan biri olarak öğretmenlerin BiT'in öğretimde nasıl kullanılacağı konusunda yeterli bilgi ve birikime sahip olmamaları 
Yabancı Dil Olarak Türkçe Öğretenlerin Eğitim Teknolojisi Standartları Öz-Yeterlik Algılarının İncelenmesi

sonucuna ulaşmış; yaşam boyu devam eden öğrenme sürecinde hizmet içi eğitimlerin önemli bir araç olduğunu vurgulamışlardır. Chen ve Thieleman $(2008$, s. 2), bugünün şartlarında bir öğretmenin sahip olması gereken bilgi ve becerileri şöyle ifade etmektedir:

- Teknolojik terimleri ve kavramları bilmek,

- Yasal ve etik normlar çerçevesinde teknolojiyi kullanabilmek,

- Teknolojiyi ve ulaşılan bilgiyi değerlendirmek ve öğrencilerin değerlendirmelerine yardımcı olabilmek,

- Öğrenmeyi pekiştirmek adına uygun teknolojik araç-gereçleri ve öğretim yöntemlerini belirleyebilmek,

- Teknolojiyi kullanarak bilgiyi öğrencilere ve diğer paydaşlara aktarabilmek,

- Öğrencilerin teknolojiyi kullanarak yaptıkları çalışmaları değerlendirebilmek,

- Dijital teknolojilere erişimde eşitlik gibi kavramların farkında olabilmek.

Teknolojinin eğitime entegrasyonu süreci öğrenci ve öğretmen rollerini etkilediği gibi yeni yöntem ve yaklaşımların ortaya çıkmasını da sağlamıştır. Aktif öğrenme, bilgiyi yapılandırma, işbirlikli öğrenme, kılavuzlu buluş yoluyla öğrenme gibi kavramlar da yeni teknolojilerin eğitimde kullanılmasıyla ortaya çıkan yaklaşımlardır (Cennamo ve diğerleri, 2010). Bilgiyi edinirken çok çeşitli yöntemler izleyen 21. yüzyıl öğrencileri bilgiyi ararken de yalnızca ders kitapları ile yetinmezler. Teknolojinin sunmuş olduğu görsel, işitsel ve çevrimiçi kaynakları da tarayarak öğrenir ve sosyal ağlar aracılığıyla bilgiyi paylaşarak öğrendiklerini pekiştirirler (Smaldino ve diğerleri, 2014).

Yeni teknolojilerin öğretme-öğrenme sürecine dâhil edilmesi gerektiğini savunan eğitimciler bu görüşlerini iki nedene dayandırarak açıklamaktadırlar. Birinci neden, dünyanın teknolojinin etkisiyle hızla değişmesi ve öğrencilerin hızla değişen bu dünyaya uyum sağlama sürecinde eğitimcilere önemli roller düşmesi; ikinci neden ise teknolojinin eğitimcilere sağladığı benzersiz olanaklardır (Collins ve Halverson, 2009). Roblyer ve Doering (2010, ss. 14-16) ise eğitimde teknoloji entegrasyonunun gerekçesini dört temel nedene dayandırmaktadır:

1. Motivasyon: Teknoloji öğrencilerin ilgisini çekerek üst düzey öğrenme becerilerinin edinimini kolaylaştırır, öğrenilenlerin gerçek yaşamla ilişkilendirilmesini sağlar, üretici becerileri geliştirir ve geniş kitlelere hitap edebilme olanağı sunar.

2. Öğretim: Teknoloji etkileşimi artırır, öğrencilere anında geribildirim sağlar. Karmaşık konuların ve soyut kavramların görselleştirilerek anlaşılmasını kolaylaştırır, problem temelli öğrenmeye elverişli yapısıyla gerçek yaşam durumlarına uygun çözümlerin üretilmesine yardımcı olur. Teknoloji öğrencilerin bilgi kaynaklarına ulaşabilmelerine, kendi öğrenme 
hızlarına ve öğrenme ihtiyaçlarına göre öğrenme ortamlarını tasarlamalarına ve işbirlikli öğrenmeye olanak tanır.

3. Üretim: Teknoloji destekli öğretim uygulamaları sayesinde öğrenme, öğretme ve değerlendirme süreçleri daha hızlı ve kolay gerçekleşmektedir. Geleneksel yöntemlere göre bilgiye erişim çok daha kolay, öğretim malzemeleri için harcanan para daha azdır.

4. Beceriler: Teknoloji, bilgi çağının en önemli gereksinimlerinden olan teknoloji okuryazarlığı, bilgi okuryazarlığı ve görsel okuryazarlık gibi 21. yüzyıl becerilerinin gelişimine önemli katkılar sağlar.

Eğitimin her kademesinde ve çeşitli konu alanlarında çok sayıda yararlarından bahsedilen eğitim teknolojisi uygulamalarının yabancı dillerin öğretiminde de önemli sorunlara çözüm arayışında kilit rol oynadığı bilinmektedir. Uluslararası düzeyde ele alındığında yabancı dil öğretiminde sıklıkla karşılan durumlardan birisi yabancı dil öğreticilerin hedef dilin doğal konuşucuları olmaması diğeri ise öğrencilerin yabancı dili kullanarak iletişime geçebilecekleri hedef kitlenin ve iletişimsel amaçların yetersizliği ya da gerçeğe uygun olmayışıdır. Teknoloji bu türden sorunların çözümünde önemli faydalar sağlar. Öğretmen ve öğrencilere dilin doğal konuşucularına ulaşabilme olanağı sunar; ses, resim, video, grafik ve animasyon gibi farklı algıları harekete geçiren çoklu ortam ögeleri ile özgün öğretim malzemeleri ve öğrenme ortamları tasarlamayı kolaylaştııır (Roblyer ve Doering, 2010).

Eğitimde teknoloji kullanımına olan ilgi arttıkça, dünya genelinde eğitimde teknolojinin etkin kullanımına yönelik yol gösterici nitelikte bir dizi standartlar geliştirilmiştir. Uluslararası Eğitim Teknolojileri Birliği'nin (The International Society for Technology in Education - ISTE) öğretimi ve öğrenmeyi desteklemek amacıyla öğretmen, öğrenci, yönetici, bilgisayar bilimi eğiticileri ve teknoloji koçlarına yönelik belirlemiş olduğu eğitim teknolojisi standartları bugün birçok ülke tarafından benimsenmiş ve eğitim teknolojilerinin kullanımı konusunda rehber olarak kabul edilmiştir.

ISTE tarafından geliştirilen ve en son 2008 yılında güncellenen, dijital çağda öğretmenlere yönelik eğitim teknolojileri standartları (The National Educational Technology Standards for Teachers - NETS-T) beş yeterlik alanı altında yirmi performans göstergesi ile açıklanmaktadır (ISTE, 2008):

1. Öğrenmeyi kolaylaştırmak, yaratıcı düşünmeyi teşvik etmek. Öğretmenler, yüz yüze ve sanal ortamlarda öğrencilerin öğrenme, yaratıcılık ve yenilenme süreçlerini destekleyici etkinlikler tasarlamak amacıyla alan bilgilerini, öğrenme-öğretme deneyimlerini ve teknolojiyi kullanırlar.

2. Dijital çağa uygun öğrenme ortamları ve değerlendirme yöntemleri tasarımlamak ve geliştirmek. Öğretmenler, öğrenmeyi en üst düzeye çıkarmak ve öğrencilerin bilgi, beceri ve 
Yabancı Dil Olarak Türkçe Öğretenlerin Eğitim Teknolojisi Standartları Öz-Yeterlik Algılarının İncelenmesi

tutumlarını geliştirmek amacıyla, modern araç-gereç ve kaynakları işe koşarak özgün öğrenme ortamları ve değerlendirme etkinlikleri tasarlar, geliştirir ve değerlendirirler.

3. Dijital çağda çalışma ve öğrenme konusunda model olmak. Öğretmenler, küresel ve dijital toplumda yeniliklere açık bir mesleğin temsilcileri olarak çalışır, bilgi, becerilerini sergilerler.

4. Dijital vatandaşlık ve sorumluluklar konusunda model olmak. Öğretmenler, sürekli değişen ve gelişen dijital toplumda yerel ve küresel boyutlardaki toplumsal sorunların ve sorumlulukların farkına varır, mesleki yaşamlarında yasal ve etik davranışlar sergilerler.

5. Mesleki gelişim ve liderlik etkinliklerine katılmak. Öğretmenler mesleki açıdan kendilerini sürekli olarak geliştirir, yaşam boyu öğrenme konusunda model olur ve görev yaptıkları okulda ve meslektaşları arasında dijital araç-gereç ve kaynakların etkin kullanımı konusunda liderlik görevi üstlenirler.

Çağın gereksinimlerini karşılayabilecek nitelikte öğretmenler yetiştirebilmek için birtakım standartların saptanması gerekmektedir (Seferoğlu, 2009). ISTE standartları, dünya genelinde eğitimcilerin program geliştirme, öğretim, mesleki gelişim ve teknoloji destekli eğitim konularında başvurabilecekleri bir yol haritasıdır. Yeterlik alanları altında tanımlanan performans göstergeleri ise belirtilen yeterlik alanları ile ilgili öğretmenlerin sahip olmaları beklenen hedef davranışlardır (ISTE, 2017). Öğretmenlere hedef davranışların kazandırılmasında atılacak en önemi adımlardan biri de öğretmenlere yönelik mesleki gelişim etkinliklerinin düzenlenmesidir. Öğretmen yeterliklerinin istenen düzeye ulaştırılmasında mesleki gelişim etkinliklerinin sürekliliğinin oldukça büyük bir öneme sahip olduğu düşünülmektedir (Seferoğlu, 2009).

Tüm dünyada olduğu gibi ülkemizde de gelişen teknolojilerin eğitime yansımaları büyük ilgi çekmektedir. Öğrenci merkezli çağdaş eğitim anlayışında teknolojinin program geliştirme, öğretim etkinlikleri ve öğrenme malzemeleri tasarlama süreçlerindeki etkisinin araştırıldığı popüler araştırmaların yanı sıra (Chen, 2013; Delgado, 2018; Er ve Er, 2013; Orhan-Karsak, 2017; Özpınar, Yenmez ve Gökçe, 2016; Shaw ve Tan, 2015), eğitimcilerin de bu süreç içerisindeki rolünü ve önemini araştıran çok sayıda araştırma bulunmaktadır (Adıgüzel ve Yüksel, 2012; Çoklar ve Odabaşı, 2010; Gündoğdu, 2018; Ilgaz ve Usluel, 2011; Mishra ve Koehler, 2006; Şimşek ve Yazar, 2017; Usluel ve diğerleri, 2007). Bu bağlamda, üzerinde düşünülmesi gereken önemli konulardan biri öğretmenlerin eğitim teknolojisi standartlarına yönelik öz yeterlikleridir.

Alanyazın incelendiğinde, Türkiye'de eğitim teknolojisi standartlarına yönelik öz yeterliklerin incelendiği çalışmaların genellikle öğretmen adayları ile yürütüldüğü anlaşılmaktadır (Çoklar, 2008; Çoklar ve Odabaşı, 2010; Kadijevich ve Haapasalo, 2008; Ozan ve Taşgın, 2017; Şimşek ve Yazar, 2018; 
Şirin ve Duman, 2013; Ulucan ve Karabulut, 2012; Yılmaz, 2018). Bu çalışmalarda, eğitim fakültelerinde okutulan eğitim teknolojileri ile ilgili dersler kapsamında öğretmen adaylarının kazanımları uluslararası standartlar genelinde değerlendirilmiştir. Öğretmenlere yönelik çalışmaların sosyal bilgiler, matematik, fen bilgisi ve İngilizce başta olmak üzere ortaokul, lise ve üniversitelerde görev yapan konu alanı öğretmenleri ve sınıf öğretmenleri ile yürütüldüğü görülmektedir (Gündoğdu, 2018; Oskay, 2017; Özçiftçi ve Çakır, 2015; Şimşek ve Yazar, 2017). Türkçenin yabancı dil olarak öğretimi alanında ise, üniversitelerde henüz bu alana yönelik bir bölüm olmadığı için öğretmen genel yeterlikleri konusunda belli bir standardın olmadığı göze çarpmaktadır. Büyükaslan (2007)'ın da ifade ettiği gibi, yabancı dil olarak Türkçe öğretiminin bir devlet politikası haline gelmesi, Türkçeyi yabancı dil olarak öğretecek kişilerin de alanın gerektirdiği donanıma sahip olmaları sağlanmalıdır. Türk Dili ve Edebiyatı, Türkçe Öğretmenliği, Yabancı Dil Öğretmenliği ve Sınıf Öğretmenliği gibi farklı alan mezunlarının görev yaptığı alanda eğitim teknolojisi standartlarına yönelik öğretmen yeterlikleri de araştırılması gereken konular arasındadır.

Bu çalışma eğitim teknolojisi standartlarına yönelik öz yeterlikler ile ilgili henüz bir araştırmanın yapılmadığı yabancı dil olarak Türkçe öğretimi alanında öğreticilerinin eğitim teknolojisi standartlarına yönelik öz yeterlik algılarını yaş, cinsiyet, öğrenim durumu, öğretim kademesi, mezuniyet alanı ve mesleki deneyim gibi çeşitli değişkenler açısından incelemeyi amaçlamaktadır. Çalışmadan elde edilen sonuçların, üniversitelerde verilen eğitimlerin dünya genelinde benimsenen eğitim teknolojileri standartlarını ne ölçüde karşıladığını ortaya koyarak alana katkı sağlayacağı düşünülmektedir.

\section{Yöntem}

\section{Araştırmanın Modeli}

Yabancı dil olarak Türkçe öğretenlerin eğitim teknolojisi standartlarına yönelik öz yeterlik algılarının araştırıldığı nicel bir araştırma olan bu çalışmada tarama modeli kullanılmıştır. Tarama araştırmaları, araştırılan konu ile ilgili anketler veya görüşmeler yoluyla hedeflenen evren içerisinden seçilen örneklemin tutumları, faaliyetleri, düşünceleri ve inanışları hakkında bilgi toplayarak istatistiksel olarak genellemeler yapmayı amaçlayan araştırmalardır (Christensen, Johnson ve Turner, 2015). Bu araştırmada, yabancı dil olarak Türkçe öğreten farklı öğretim kademesindeki öğreticilerin eğitim teknolojisi standartlarına yönelik öz yeterlik algıları çeşitli değişkenler açısından betimlenmiştir. Araştırmanın amaçları aşağıdaki gibidir:

1. Yabancı dil olarak Türkçe öğretenlerin eğitim teknolojisi standartları öz yeterlik algıları ne düzeydedir? 
2. Yabancı dil olarak Türkçe öğretenlerin eğitim teknolojisi standartları öz yeterlik algıları yaş bağlamında istatistiksel olarak anlamlı bir farklılık göstermekte midir?

3. Yabancı dil olarak Türkçe öğretenlerin eğitim teknolojisi standartları öz yeterlik algıları cinsiyet bağlamında istatistiksel olarak anlamlı bir farklılık göstermekte midir?

4. Yabancı dil olarak Türkçe öğretenlerin eğitim teknolojisi standartları öz yeterlik algıları öğrenim durumu bağlamında istatistiksel olarak anlamlı bir farklılık göstermekte midir?

5. Yabancı dil olarak Türkçe öğretenlerin eğitim teknolojisi standartları öz yeterlik algıları öğretim kademesi bağlamında istatistiksel olarak anlamlı bir farklılık göstermekte midir?

6. Yabancı dil olarak Türkçe öğretenlerin eğitim teknolojisi standartları öz yeterlik algıları mezuniyet alanı bağlamında istatistiksel olarak anlamlı bir farklılık göstermekte midir?

7. Yabancı dil olarak Türkçe öğretenlerin eğitim teknolojisi standartları öz yeterlik algıları mesleki deneyim bağlamında istatistiksel olarak anlamlı bir farklılık göstermekte midir?

\section{Evren ve Örneklem}

Araştırmanın evrenini, 2018-2019 eğitim ve öğretim yılının güz döneminde yurtdışında ve Türkiye'nin çeşitli illerinde ilk, orta ve yükseköğretim kurumlarında yabancılara Türkçe öğreten öğretmenler oluşturmaktadır. Araştırmanın örneklemini ise küme örnekleme yöntemi ile belirlenmiş yabancı dil olarak Türkçe öğreten 287 öğretmen oluşturmaktadır. Küme örnekleme evren hacminin geniş ve evreni oluşturan birimlere ulaşmanın zor olduğu durumlarda başvurulan bir yöntemdir (Şahin, 2014; Ural ve Kılıç, 2011). Küme örneklemede evren, kendi içinde benzer özelliklere sahip alt evrenlere, bir başka deyişle kümelere ayrılır. Belirlenen bu kümeler içerisindeki birimler örneklemi oluşturur (Akarsu, 2016; Karasar, 2014; Ural ve Kılıç, 2011). Örneklem içerisinden 229 öğretmen uygulanan ölçeği zamanında ve eksiksiz bir şekilde tamamlayarak çalışmaya veri sağlamıştır. Örneklemi oluşturan öğretmenlere ilişkin demografik bilgiler Tablo 1'de gösterilmektedir.

Tablo 1. Araştırma grubunun demografik özellikleri

\begin{tabular}{|l|l|c|c|}
\hline \multicolumn{1}{|c|}{ Değişken } & \multicolumn{1}{|c|}{ Özellikler } & N & \% \\
\hline \multirow{3}{*}{ Yaş } & $22-27$ & 120 & 52.4 \\
& $28-35$ & 79 & 34.5 \\
& $36-42$ & 22 & 9.6 \\
& 43 ve üzeri & 8 & 3.5 \\
\hline \multirow{2}{*}{ Cinsiyet } & Erkek & 69 & 30.1 \\
& Kadın & 160 & 69.9 \\
\hline \multirow{2}{*}{ Öğrenim Durumu } & Lisans & 206 & 90 \\
& Yüksek Lisans & 15 & 6.6 \\
\hline \multirow{2}{*}{ Öğretim Kademesi } & Doktora & 62 & 3.5 \\
\hline
\end{tabular}




\begin{tabular}{|l|l|c|c|}
\hline \multirow{5}{*}{} & Ortaöğretim & 55 & 24 \\
& Yükseköğretim & 24 & 10.5 \\
& Yetişkin & 88 & 38.4 \\
\hline & Türkçe Öğretmenliği & 46 & 20.1 \\
& Türk Dili ve Edebiyatı & 110 & 48 \\
& Sinıf Öğretmenliği & 45 & 19.7 \\
& Yabancı Dil Öğretimi (ingilizce, Almanca..) & 14 & 6.1 \\
& Psikolojik Danışma ve Rehberlik & 6 & 2.6 \\
& Güzel Sanatlar & 3 & 1.3 \\
& Beden Eğitimi Öğretmenliği & 1 & 0.4 \\
& Sosyal Bilgiler Öğretmenliği & 3 & 1.3 \\
& Fen Bilgisi Öğretmenliği & 1 & 0.4 \\
\hline \multirow{5}{*}{ Deneyim } & $0-11$ ay & 36 & 15.7 \\
& $12-23$ ay & 32 & 14.0 \\
& $24-35$ ay & 53 & 23.1 \\
& 3-5 yıl & 50 & 21.8 \\
& 5-10 yıl & 31 & 13.5 \\
& 11 yıl ve üzeri & 27 & 11.8 \\
\hline
\end{tabular}

\section{Veri Toplama Araçları}

Araştırmada veri toplama aracı olarak kullanılan anket formu iki bölümden oluşmaktadır. Öğretmenlerin kişisel bilgilerinin sorulduğu birinci bölümde 6 madde yer almaktadır. İkinci bölümde ise, Şimsek ve Yazar (2016) tarafından ISTE'nin öğretmenlere yönelik eğitim teknolojisi standartları çerçevesinde geliştirilen "Eğitim Teknolojisi Standartları Öz Yeterlik Ölçeği” kullanılmıştır. 5'li Likert tipinde (5. Tamamen katılıyorum, 4. Katılıyorum, 3. Biraz katılıyorum, 2. Katılmıyorum, 1. Tamamen katılmıyorum) ve 40 maddeden oluşan ölçek ISTE'nin öğretmen yeterlikleri dikkate alınarak 5 alt boyutlu olarak tasarlanmıştır. Eğitim Teknolojisi Standartlarına Yönelik Öz Yeterlik (ETSYÖ) ölçeğinin alt boyutları ve madde sayıları şu şekildedir:

1. Öğrencilerin öğrenmelerini kolaylaştırma ve yaratıcılığı teşvik etme (1-9 maddeler)

2. Dijital çağa uygun öğrenme ortamları ve değerlendirme etkinlikleri tasarımlama ve geliştirme (10-19 maddeler)

3. Dijital çağın çalışma ve öğrenme anlayışına öncülük etme (20-24 maddeler)

4. Dijital vatandaşlıkta model olma (25-31 maddeler)

5. Mesleki gelişim ve liderlik etkinliklerine katılma (32-40 maddeler)

\section{Verilerin Çözümlenmesi}

Yabancı dil olarak Türkçe öğretenlerin eğitim teknolojisi standartları öz yeterlik algıları ETSYÖ ölçeğinden aldıkları puanların aritmetik ortalamaları değerlendirilerek belirlenmiştir. Ölçekten elde 
edilen ortalama puanlar "1.00-1.80: Hiç katılmıyorum, 1.81-2.60: Katılmıyorum, 2.61-3.40: Biraz katılıyorum, 3.41-4.20: Katılıyorum ve 4.21-5.00: Tamamen katılıyorum" temel alınarak değerlendirilmiştir. Ortalama puanların 3 'ten düşük olması durumunda öğretmenlerin eğitim teknolojisi standartları öz yeterlikleri düşük, 3 olması durumunda orta, 3 'ten yüksek olması halinde ise yüksek düzeyde olarak yorumlanmıştır. Ölçekten elde edilen veriler üzerinde SPSS 22.0 (Statistical Package for the Social Sciences) programı kullanılarak yüzde, sıklık, aritmetik ortalama ve standart sapma gibi betimsel istatistik analizleri yapılmış; öğretmenlerin eğitim teknolojisi standartlarına yönelik öz yeterliklerinin ilgili değişkenler bağlamında değerlendirilebilmesi amacıyla öz yeterlik puan ortalamaları karşılaştırılmıştır. Verilerin değerlendirilmesi ile elde edilen sonuçlar 0.05 anlamlılık düzeyi dikkate alınarak yorumlanmıştır.

\section{Bulgular}

Yabancı dil olarak Türkçe öğreticilerinin eğitim teknolojisi standartlarına yönelik öz yeterliklerini belirlemek amacıyla ETSYÖ ölçeğinden elde edilen veriler nicel veri analiz yöntemleri kullanılarak değerlendirilmiş ve ilgili araştırma soruları kapsamında yorumlanmıştır.

\section{Yabancı Dil Olarak Türkçe Öğretenlerin Eğitim Teknolojisi Standartlarına Yönelik Öz Yeterlikleri}

İstatistiksel analizlere başlamadan önce ilk olarak "Normal Dağılım Testi” uygulanarak verilerin normal dağılıp dağılmadığı araştıııımıştır. Normallik varsayımına ilişkin bulgular Tablo 2'de gösterilmiştir.

Tablo 2. ETSYÖ ölçeği normal dağılım testi sonuçları

\begin{tabular}{|l|c|c|c|}
\hline \multirow{2}{*}{ Alt Boyutlar } & \multicolumn{3}{|c|}{ Shapiro-Wilk } \\
\cline { 2 - 4 } & Statistic & sd & $p$ \\
\hline $\begin{array}{l}\text { Öğrencilerin öğrenmelerini kolaylaştırma ve yaratııılığı } \\
\text { teşvik etme }\end{array}$ & 0.75 & 229 & 0.00 \\
\hline $\begin{array}{l}\text { Dijital çağa uygun öğrenme ortamları ve değerlendirme } \\
\text { etkinlikleri tasarımlama ve geliştirme }\end{array}$ & 0.80 & 229 & 0.00 \\
\hline Dijital çağın çalışma ve öğrenme anlayışına öncülük etme & 0.78 & 229 & 0.00 \\
\hline Dijital vatandaşlıkta model olma & 0.79 & 229 & 0.00 \\
\hline Mesleki gelişim ve liderlik etkinliklerine katııma & 0.75 & 229 & 0.00 \\
\hline ETSYÖ Genel & 0.75 & 229 & 0.00 \\
\hline
\end{tabular}

Tablo 2'de de görüldüğü gibi yapılan Shapiro-Wilk testi sonuçlarına göre normal dağılmadığı belirlenen veriler için parametrik olmayan istatistik yöntemleri kullanılmıştır. Öğretmenlerin eğitim 
teknolojisi standartlarına yönelik öz yeterliklerine ilişkin aritmetik ortalamalar ve standart sapma değerleri hesaplanmış, sonuçlar Tablo 3'te gösterilmiştir.

Tablo 3. ETSYÖ̈̈lçeği betimsel istatistik verileri

\begin{tabular}{|l|c|c|c|}
\hline Alt Boyutlar & $\mathrm{N}$ & ⿴囗 & Ss \\
\hline $\begin{array}{l}\text { Öğrencilerin öğrenmelerini kolaylaştırma ve yaratııı Ĭı̆ı teşvik etme (1-9 } \\
\text { maddeler) }\end{array}$ & 229 & 3.90 & 0.63 \\
\hline $\begin{array}{l}\text { Dijital çağa uygun öğrenme ortamları ve değerlendirme etkinlikleri } \\
\text { tasarımlama ve geliştirme (10-19 maddeler) }\end{array}$ & 229 & 3.76 & 0.73 \\
\hline $\begin{array}{l}\text { Dijital çağın çalışma ve öğrenme anlayışına öncülük etme (20-24 } \\
\text { maddeler) }\end{array}$ & 229 & 3.82 & 0.72 \\
\hline Dijital vatandaşıkta model olma (25-31 maddeler) & 229 & 3.82 & 0.70 \\
\hline Mesleki gelişim ve liderlik etkinliklerine katılma (32-40 maddeler) & 229 & 3.93 & 0.65 \\
\hline ETSYö Genel & 229 & 3.85 & 0.61 \\
\hline
\end{tabular}

Ölçeğin genelinden elde edilen sonuçlara bakılacak olursa, öğretmenlerin eğitim teknolojisi standartlarına yönelik öz yeterlik ortalama puanlarının $\bar{x}=3.85$ olduğu görülmektedir. Bu bulgulara göre yabancı dil olarak Türkçe öğreten öğretmenlerin eğitim teknolojisi standartlarını büyük oranda karşıladığı söylenebilir. Ölçekten elde edilen veriler ölçeğin alt boyutları bağlamında değerlendirilecek olursa en yüksek ortalama puanın "Mesleki gelişim ve liderlik etkinliklerine katılma" alt boyutundan ( $\bar{x}=3.93$ ) alındığı görülmektedir. Bu sonuçlar, yabancı dil olarak Türkçe öğreten öğretmenlerin mesleki gelişimlerini sürdürebilmek için teknolojiyi etkin bir şekilde kullanabildiklerini ve teknolojik gelişmelere açık olduklarını göstermektedir. Ölçeğin alt boyutları arasında en düşük ortalama puan "Dijital çağa uygun öğrenme ortamları ve değerlendirme etkinlikleri tasarımlama ve geliştirme" alt boyutundan ( $\bar{x}=3.76)$ elde edilmiş olsa da, bu sonuçlar öğretmenlerin teknolojiyi kullanarak öğrenme ortamları ve değerlendirme etkinlikleri tasarlama konusunda kendilerini yeterli gördüklerini ortaya koymaktadır.

Ölçeğin diğer alt boyutlarından elde edilen ortalama puanların “Öğrencilerin öğrenmelerini kolaylaştırma ve yaratıcılığı teşvik etme" alt boyutu için $\bar{x}=3.90$, "Dijital çağın çalışma ve öğrenme anlayışına öncülük etme" alt boyutu için $\bar{x}=3.82$, "Dijital vatandaşlıkta model olma" alt boyutu için $\bar{x}=3.82$ olduğu görülmektedir. En düşük ortalama puanın alındığı “Dijital çağa uygun öğrenme ortamları ve değerlendirme etkinlikleri tasarımlama ve geliştirme" alt boyutu da dâhil olmak üzere tüm alt boyutlardan alınan ortalama puanlar, yabancı dil olarak Türkçe öğreten öğretmenlerin teknolojiyi eğitim sürecine dâhil edebilme yeterliklerinin yüksek düzeyde olduğu sonucunu ortaya koymaktadır. 
Eğitim Teknolojisi Standartlarına Yönelik Öz Yeterlikler ile Yaş Değişkeni Arasındaki Ilişski

Yabancı dil olarak Türkçe öğreten öğretmenlerin eğitim teknolojisi standartlarına yönelik öz yeterlik algılarının yaş değişkeni bağlamında anlamlı ölçüde farklılaşma durumuna ilişkin Kruskal WallisH Testi yapılmış, sonuçlar Tablo 4'te gösterilmiştir.

Tablo 4. ETSYÖ algılarının yaş değişkenine göre farklılaşma durumu

\begin{tabular}{|c|c|c|c|c|c|c|c|}
\hline Alt Boyutlar & Yaş & $\mathrm{N}$ & Sira Ort. & sd & Ki-Kare & $p$ & Anlamlı Fark \\
\hline \multirow{4}{*}{$\begin{array}{l}\text { Öğrenmeyi } \\
\text { kolaylaştırma ve } \\
\text { yaratıcılığı teşvik } \\
\text { etme }\end{array}$} & $22-27$ & 120 & 125.34 & \multirow{4}{*}{3} & \multirow{4}{*}{7.76} & \multirow{4}{*}{0.05} & \\
\hline & $28-35$ & 79 & 99.94 & & & & \\
\hline & $36-42$ & 22 & 119.16 & & & & \\
\hline & $43+$ & 8 & 97.25 & & & & \\
\hline \multirow{4}{*}{$\begin{array}{l}\text { Öğrenme ortamları } \\
\text { ve değerlendirme } \\
\text { etkinlikleri } \\
\text { tasarımlama }\end{array}$} & $22-27$ & 120 & 128.83 & \multirow{4}{*}{3} & \multirow{4}{*}{11.92} & \multirow{4}{*}{0.01} & \multirow{4}{*}{$\begin{array}{l}1-3 \\
1-4 \\
2-4\end{array}$} \\
\hline & $28-35$ & 79 & 99.65 & & & & \\
\hline & $36-42$ & 22 & 106.91 & & & & \\
\hline & $43+$ & 8 & 81.38 & & & & \\
\hline \multirow{4}{*}{$\begin{array}{l}\text { Dijital çağın } \\
\text { çalışma ve } \\
\text { öğrenme anlayışına } \\
\text { öncülük etme }\end{array}$} & $22-27$ & 120 & 127.69 & \multirow{4}{*}{3} & \multirow{4}{*}{9.89} & \multirow{4}{*}{0.02} & \multirow{4}{*}{$\begin{array}{l}1-3 \\
1-4\end{array}$} \\
\hline & $28-35$ & 79 & 103.41 & & & & \\
\hline & $36-42$ & 22 & 97.66 & & & & \\
\hline & $43+$ & 8 & 86.88 & & & & \\
\hline \multirow{4}{*}{$\begin{array}{l}\text { Dijital } \\
\text { vatandaşlıkta } \\
\text { model olma }\end{array}$} & $22-27$ & 120 & 120.14 & \multirow{4}{*}{3} & \multirow{4}{*}{4.63} & \multirow{4}{*}{0.20} & \\
\hline & 28-35 & 79 & 109.82 & & & & \\
\hline & $36-42$ & 22 & 120.84 & & & & \\
\hline & $43+$ & 8 & 73.00 & & & & \\
\hline \multirow{4}{*}{$\begin{array}{l}\text { Mesleki gelişim ve } \\
\text { liderlik } \\
\text { etkinliklerine } \\
\text { katılma }\end{array}$} & $22-27$ & 120 & 127.70 & \multirow{4}{*}{3} & \multirow{4}{*}{9.89} & \multirow{4}{*}{0.02} & \multirow{4}{*}{$\begin{array}{l}1-3 \\
1-4 \\
2-4\end{array}$} \\
\hline & $28-35$ & 79 & 102.42 & & & & \\
\hline & $36-42$ & 22 & 102.00 & & & & \\
\hline & $43+$ & 8 & 84.50 & & & & \\
\hline \multirow{4}{*}{ ETSYÖ Genel } & $22-27$ & 120 & 127.62 & \multirow{4}{*}{3} & \multirow{4}{*}{10.21} & \multirow{4}{*}{0.02} & \multirow{4}{*}{$\begin{array}{l}1-3 \\
1-4\end{array}$} \\
\hline & $28-35$ & 79 & 101.23 & & & & \\
\hline & $36-42$ & 22 & 108.18 & & & & \\
\hline & $43+$ & 8 & 80.38 & & & & \\
\hline
\end{tabular}

Tablo 4'teki sonuçlar incelendiğinde eğitim teknolojisi standartlarına yönelik öz yeterlik algılarının yaş değişkenine göre ölçeğin genelinde (Ki-Kare=10.21; $p<0.05$ ) ve "Dijital çağa uygun öğrenme ortamları ve değerlendirme etkinlikleri tasarımlama ve geliştirme" (Ki-Kare=11.92; $p<0.05)$, "Dijital çağın çalışma ve öğrenme anlayışına öncülük etme" (Ki-Kare=9.89; $p<0.05)$, "Mesleki gelişim ve liderlik etkinliklerine katılma" (Ki-Kare=9.89; p<0.05) alt boyutlarında anlamlı ölçüde farklılaştığı görülmektedir. "Öğrencilerin öğrenmelerini kolaylaştırma ve yaratıcılığı teşvik etme" (Ki-Kare=7.76; 
$p>0.05)$ ile "Dijital vatandaşlıkta model olma" (Ki-Kare=4.63; $p>0.05)$ alt boyutlarında ise anlamlı bir farklııı̆a rastlanmamıştır. Ölçeğin geneli ve "Dijital vatandaşlıkta model olma" alt boyutu dışındaki diğer alt boyutlarda 22-27 yaş grubundaki yabancı dil olarak Türkçe öğreten öğretmenlerin eğitim teknolojisi standartlarına yönelik öz yeterlik algılarının diğer yaş grubundaki öğretmenlere göre daha yüksek olduğu göze çarpmaktadır. Öğretmenlerin eğitim teknolojisi standartları öz yeterlik algılarııın ölçeğin genelinde ve "Dijital çağa uygun öğrenme ortamları ve değerlendirme etkinlikleri tasarımlama ve geliştirme”, "Dijital çağın çalışma ve öğrenme anlayışına öncülük etme”, "Mesleki gelişim ve liderlik etkinliklerine katılma" alt boyutlarında "22-27" yaş grubundaki öğretmenler ile "36-42" ve "43 ve üzeri” yaş gruplarındaki öğretmenler arasında "22-27" grubundaki öğretmenler lehine anlamlı ölçüde farklılaştığı görülmektedir. Ayrıca, “Dijital çağa uygun öğrenme ortamları ve değerlendirme etkinlikleri tasarımlama ve geliştirme" ve "Mesleki gelişim ve liderlik etkinliklerine katılma" alt boyutlarında "2835" yaş grubundaki öğretmenlerin öz yeterlik algılarının "43 ve üzeri” yaş grubundaki öğretmenlerden anlamlı ölçüde daha yüksek olduğu anlaşılmıştır.

\section{Eğitim Teknolojisi Standartlarına Yönelik Öz Yeterlikler ile Cinsiyet Değişkeni Arasındaki ilişski}

Türkçeyi yabancı dil olarak öğretenlerin eğitim teknolojisi standartlarına yönelik öz yeterlik algılarının cinsiyet değişkeni bağlamında anlamlı ölçüde farklılaşıp farklılaşmadığını belirlemek amacıyla Mann-Whitney U Testi yapılmış, sonuçlar Tablo 5'te gösterilmiştir.

Tablo 4. ETSYÖ algılarının cinsiyet değişkenine göre farklılaşma durumu

\begin{tabular}{|c|c|c|c|c|c|c|c|}
\hline Alt Boyutlar & Cinsiyet & $\mathrm{N}$ & Sira Ort. & Sira Top. & $\mathrm{U}$ & $Z$ & $p$ \\
\hline \multirow{2}{*}{$\begin{array}{l}\text { Öğrenmeyi } \\
\text { kolaylaştırma ve } \\
\text { yaratıcılığı teşvik } \\
\text { etme }\end{array}$} & Erkek & 69 & 116.83 & 8061.00 & \multirow[b]{2}{*}{5394.00} & \multirow[b]{2}{*}{-0.28} & \multirow[b]{2}{*}{0.78} \\
\hline & Kadın & 160 & 114.21 & 18274.00 & & & \\
\hline \multirow{2}{*}{$\begin{array}{l}\text { Öğrenme ortamları } \\
\text { ve değerlendirme } \\
\text { etkinlikleri } \\
\text { tasarımlama }\end{array}$} & Erkek & 69 & 110.71 & 7639.00 & \multirow[b]{2}{*}{5224.00} & \multirow[b]{2}{*}{-0.65} & \multirow[b]{2}{*}{0.52} \\
\hline & Kadın & 160 & 116.85 & 18696.00 & & & \\
\hline \multirow{2}{*}{$\begin{array}{l}\text { Dijital çağın çalışma } \\
\text { ve öğrenme } \\
\text { anlayışına öncülük } \\
\text { etme }\end{array}$} & Erkek & 69 & 108.93 & 7516.50 & \multirow[b]{2}{*}{5101.50} & \multirow[b]{2}{*}{-0.92} & \multirow[b]{2}{*}{0.36} \\
\hline & Kadın & 160 & 117.62 & 18818.50 & & & \\
\hline \multirow{2}{*}{$\begin{array}{l}\text { Dijital vatandaşlıkta } \\
\text { model olma }\end{array}$} & Erkek & 69 & 108.20 & 7466.00 & \multirow{2}{*}{5051.00} & \multirow{2}{*}{-1.02} & \multirow{2}{*}{0.31} \\
\hline & Kadın & 160 & 117.93 & 18869.00 & & & \\
\hline \multirow{2}{*}{$\begin{array}{l}\text { Mesleki gelişim ve } \\
\text { liderlik } \\
\text { etkinliklerine } \\
\text { katılma }\end{array}$} & Erkek & 69 & 109.57 & 7560.50 & \multirow[b]{2}{*}{5145.50} & \multirow[b]{2}{*}{-0.82} & \multirow[b]{2}{*}{ 0. .41 } \\
\hline & Kadın & 160 & 117.34 & 18774.50 & & & \\
\hline \multirow{2}{*}{ ETSYÖ Genel } & Erkek & 69 & 109.69 & 7568.50 & \multirow{2}{*}{5153.50} & \multirow{2}{*}{-0.80} & \multirow{2}{*}{0.43} \\
\hline & Kadın & 160 & 117.29 & 18766.50 & & & \\
\hline
\end{tabular}


Yabancı Dil Olarak Türkçe Öğretenlerin Eğitim Teknolojisi Standartları Öz-Yeterlik Algılarının İncelenmesi

Tablo 5'teki sonuçlara göre yabancı dil olarak Türkçe öğreticilerinin eğitim teknolojisi standartları öz yeterlik algılarının cinsiyet değişkeni bağlamında ölçeğin geneli (U=5153.5; $p>0.05)$ ve tüm alt boyutlarında anlamlı ölçüde farklılaşmadığı görülmektedir.

Eğitim Teknolojisi Standartlarına Yönelik Öz Yeterlikler ile Öğrenim Durumu Değişkeni Arasındaki Ilişski

Eğitim teknolojisi standartlarına yönelik öz yeterlik algılarının öğrenim durumu değişkeni bağlamında farklılaşma durumuna ilişkin Kruskal Wallis-H Testi yapılmış, sonuçlar Tablo 6'da gösterilmiştir.

Tablo 5. ETSYÖ algılarının öğrenim durumu değişkenine göre farklılaşma durumu

\begin{tabular}{|c|c|c|c|c|c|c|c|}
\hline Alt Boyutlar & Öğr. Dur. & $\mathrm{N}$ & Sıra Ort. & $s d$ & Ki-Kare & $p$ & Anlamlı Fark \\
\hline \multirow{3}{*}{$\begin{array}{l}\text { Öğrenmeyi } \\
\text { kolaylaştırma ve } \\
\text { yaratıcılığı teşvik } \\
\text { etme }\end{array}$} & Lisans & 206 & 114.69 & \multirow{3}{*}{2} & \multirow{3}{*}{0.07} & \multirow{3}{*}{0.96} & \\
\hline & Y. Lisans & 15 & 119.47 & & & & \\
\hline & Doktora & 8 & 114.56 & & & & \\
\hline \multirow{3}{*}{$\begin{array}{l}\text { Öğrenme ortamları } \\
\text { ve değerlendirme } \\
\text { etkinlikleri } \\
\text { tasarımlama }\end{array}$} & Lisans & 206 & 114.95 & \multirow{3}{*}{2} & \multirow{3}{*}{0.79} & \multirow{3}{*}{0.67} & \\
\hline & Y. Lisans & 15 & 124.40 & & & & \\
\hline & Doktora & 8 & 98.69 & & & & \\
\hline \multirow{3}{*}{$\begin{array}{l}\text { Dijital çağın } \\
\text { çalışma ve } \\
\text { öğrenme anlayışına } \\
\text { öncülük etme }\end{array}$} & Lisans & 206 & 114.57 & \multirow{3}{*}{2} & \multirow{3}{*}{1.41} & \multirow{3}{*}{0.50} & \\
\hline & Y. Lisans & 15 & 130.37 & & & & \\
\hline & Doktora & 8 & 97.25 & & & & \\
\hline \multirow{3}{*}{$\begin{array}{l}\text { Dijital } \\
\text { vatandaşlıkta } \\
\text { model olma }\end{array}$} & Lisans & 206 & 114.95 & \multirow{3}{*}{2} & \multirow{3}{*}{0.51} & \multirow{3}{*}{0.78} & \\
\hline & Y. Lisans & 15 & 122.60 & & & & \\
\hline & Doktora & 8 & 102.06 & & & & \\
\hline \multirow{3}{*}{$\begin{array}{l}\text { Mesleki gelişim ve } \\
\text { liderlik } \\
\text { etkinliklerine } \\
\text { katılma }\end{array}$} & Lisans & 206 & 115.77 & \multirow{3}{*}{2} & \multirow{3}{*}{1.27} & \multirow{3}{*}{0.53} & \\
\hline & Y. Lisans & 15 & 118.10 & & & & \\
\hline & Doktora & 8 & 89.38 & & & & \\
\hline \multirow{3}{*}{ ETSYÖ Genel } & Lisans & 206 & 115.18 & \multirow{3}{*}{2} & \multirow{3}{*}{0.52} & \multirow{3}{*}{0.77} & \\
\hline & Y. Lisans & 15 & 120.57 & & & & \\
\hline & Doktora & 8 & 100.00 & & & & \\
\hline
\end{tabular}

Bu sonuçlara göre, yabancı dil olarak Türkçe öğreten öğretmenlerin eğitim teknolojisi standartları öz yeterlik algıları öğrenim durumlarına göre değerlendirildiğinde ölçeğin genelinde (KiKare $=0.52 ; p>0.05$ ) ve tüm alt boyutlarında anlamlı farklılık bulunmamaktadır.

Eğitim Teknolojisi Standartlarına Yönelik Öz Yeterlikler ile Öğretim Kademesi Değişkeni Arasındaki ilişski

Öğretmenlerin görev yaptıkları öğretim kademesi bağlamında eğitim teknolojisi standartları öz yeterlik algılarının farklılaşma durumunu incelemek üzere Kruskal Wallis-H Testi yapılmış, sonuçlar Tablo 7'de gösterilmiştir. 
Tablo 6. ETSYÖ algılarının öğretim kademesi değişkenine göre farklılaşma durumu

\begin{tabular}{|c|c|c|c|c|c|c|c|}
\hline Alt Boyutlar & Öğr. Kad. & $\mathrm{N}$ & Sira Ort. & sd & Ki-Kare & $p$ & Anlamlı Fark \\
\hline \multirow{4}{*}{$\begin{array}{l}\text { Öğrenmeyi } \\
\text { kolaylaştırma ve } \\
\text { yaratıcılığı teşvik } \\
\text { etme }\end{array}$} & İlköğretim & 62 & 116.23 & \multirow{4}{*}{3} & \multirow{4}{*}{1.82} & \multirow{4}{*}{0.61} & \\
\hline & Ortaöğretim & 55 & 105.51 & & & & \\
\hline & Yükseköğretim & 24 & 124.92 & & & & \\
\hline & Yetişkinler & 88 & 117.36 & & & & \\
\hline \multirow{4}{*}{$\begin{array}{l}\text { Öğrenme } \\
\text { ortamları ve } \\
\text { değerlendirme } \\
\text { etkinlikleri } \\
\text { tasarımlama }\end{array}$} & Ilköğretim & 62 & 124.86 & \multirow{4}{*}{3} & \multirow{4}{*}{3.92} & \multirow{4}{*}{0.27} & \\
\hline & Ortaöğretim & 55 & 100.95 & & & & \\
\hline & Yükseköğretim & 24 & 116.00 & & & & \\
\hline & Yetişkinler & 88 & 116.56 & & & & \\
\hline \multirow{4}{*}{$\begin{array}{l}\text { Dijital çağın } \\
\text { çalışma ve } \\
\text { öğrenme } \\
\text { anlayışına öncülük } \\
\text { etme }\end{array}$} & ilköğretim & 62 & 128.65 & \multirow{4}{*}{3} & \multirow{4}{*}{4.86} & \multirow{4}{*}{0.18} & \\
\hline & Ortaöğretim & 55 & 102.45 & & & & \\
\hline & Yükseköğretim & 24 & 109.02 & & & & \\
\hline & Yetişkinler & 88 & 114.85 & & & & \\
\hline \multirow{4}{*}{$\begin{array}{l}\text { Dijital } \\
\text { vatandaşlıkta } \\
\text { model olma }\end{array}$} & İlköğretim & 62 & 122.95 & \multirow{4}{*}{3} & \multirow{4}{*}{2.08} & \multirow{4}{*}{0.56} & \\
\hline & Ortaöğretim & 55 & 106.49 & & & & \\
\hline & Yükseköğretim & 24 & 108.60 & & & & \\
\hline & Yetişkinler & 88 & 116.46 & & & & \\
\hline \multirow{4}{*}{$\begin{array}{l}\text { Mesleki gelişim ve } \\
\text { liderlik } \\
\text { etkinliklerine } \\
\text { katılma }\end{array}$} & İlköğretim & 62 & 125.06 & \multirow{4}{*}{3} & \multirow{4}{*}{6.00} & \multirow{4}{*}{0.11} & \\
\hline & Ortaöğretim & 55 & 99.53 & & & & \\
\hline & Yükseköğretim & 24 & 102.81 & & & & \\
\hline & Yetişkinler & 88 & 120.91 & & & & \\
\hline \multirow{4}{*}{ ETSYÖ Genel } & Illköğretim & 62 & 124.59 & \multirow{4}{*}{3} & \multirow{4}{*}{3.33} & \multirow{4}{*}{0.34} & \\
\hline & Ortaöğretim & 55 & 102.55 & & & & \\
\hline & Yükseköğretim & 24 & 112.69 & & & & \\
\hline & Yetişkinler & 88 & 116.65 & & & & \\
\hline
\end{tabular}

Tablo 7'deki sonuçlar değerlendirildiğinde, ilköğretim, ortaöğretim, yükseköğretim ve yetişkinler olmak üzere farklı öğretim kademelerinde görev yapan yabancı dil olarak Türkçe öğretmenlerinin eğitim teknolojisi standartlarına yönelik öz yeterlik algılarının ölçeğin geneli (KiKare=3.33; $p>0.05$ ) ve tüm alt boyutlarında istatistiksel olarak anlamlı ölçüde farklılaşmadığı anlaşıımaktadır.

Eğitim Teknolojisi Standartlarına Yönelik Öz Yeterlikler ile Mezuniyet Alanı Değişkeni Arasındaki ilişki

Yabancı Dil Olarak Türkçe Öğretimi alanında görevli öğretmenlerin eğitim teknolojisi standartları öz yeterlik algılarının mezun oldukları alan değişkeni bağlamında farklılaşma durumu Kruskal Wallis-H Testi ile incelenmiş, sonuçlar Tablo 8' de gösterilmiştir. 
Tablo 7. ETSYÖ algılarının mezuniyet alanı değişkenine göre farklılaşma durumu

\begin{tabular}{|c|c|c|c|c|c|c|c|}
\hline Alt Boyutlar & Mezuniyet & $\mathrm{N}$ & Sıra Ort. & sd & Ki-Kare & $p$ & Anlamlı Fark \\
\hline \multirow{5}{*}{$\begin{array}{l}\text { Öğrenmeyi } \\
\text { kolaylaştırma ve } \\
\text { yaratıcılığı teşvik } \\
\text { etme }\end{array}$} & Türkçe Öğrt. & 46 & 110.86 & \multirow{5}{*}{4} & \multirow{5}{*}{4.06} & \multirow{5}{*}{0.40} & \\
\hline & Türk Dili ve Ed. & 110 & 123.33 & & & & \\
\hline & Sınıf Öğrt. & 45 & 101.12 & & & & \\
\hline & Yabancı Dil Öğrt. & 14 & 113.82 & & & & \\
\hline & Diğer & 14 & 108.96 & & & & \\
\hline \multirow{5}{*}{$\begin{array}{l}\text { Öğrenme ortamları } \\
\text { ve değerlendirme } \\
\text { etkinlikleri } \\
\text { tasarımlama }\end{array}$} & Türkçe Öğrt. & 46 & 110.86 & \multirow{5}{*}{4} & \multirow{5}{*}{1.54} & \multirow{5}{*}{0.82} & \\
\hline & Türk Dili ve Ed. & 110 & 123.33 & & & & \\
\hline & Sınıf Öğrt. & 45 & 101.12 & & & & \\
\hline & Yabancı Dil Öğrt. & 14 & 113.82 & & & & \\
\hline & Diğer & 14 & 108.96 & & & & \\
\hline \multirow{5}{*}{$\begin{array}{l}\text { Dijital çağın } \\
\text { çalışma ve } \\
\text { öğrenme } \\
\text { anlayışına öncülük } \\
\text { etme }\end{array}$} & Türkçe Öğrt. & 46 & 110.86 & \multirow{5}{*}{4} & \multirow{5}{*}{0.38} & \multirow{5}{*}{0.98} & \\
\hline & Türk Dili ve Ed. & 110 & 123.33 & & & & \\
\hline & Sınıf Öğrt. & 45 & 101.12 & & & & \\
\hline & Yabancı Dil Öğrt. & 14 & 113.82 & & & & \\
\hline & Diğer & 14 & 108.96 & & & & \\
\hline \multirow{5}{*}{$\begin{array}{l}\text { Dijital } \\
\text { vatandaşlıkta } \\
\text { model olma }\end{array}$} & Türkçe Öğrt. & 46 & 110.86 & \multirow{5}{*}{4} & \multirow{5}{*}{5.61} & \multirow{5}{*}{0.23} & \\
\hline & Türk Dili ve Ed. & 110 & 123.33 & & & & \\
\hline & Sınıf Öğrt. & 45 & 101.1 & & & & \\
\hline & Yabancı Dil Öğrt. & 14 & 113.82 & & & & \\
\hline & Diğer & 14 & 108.96 & & & & \\
\hline \multirow{5}{*}{$\begin{array}{l}\text { Mesleki gelişim ve } \\
\text { liderlik } \\
\text { etkinliklerine } \\
\text { katılma }\end{array}$} & Türkçe Öğrt. & 46 & 110.86 & \multirow{5}{*}{4} & \multirow{5}{*}{2.84} & \multirow{5}{*}{0.59} & \\
\hline & Türk Dili ve Ed. & 110 & 123.33 & & & & \\
\hline & Sınıf Öğrt. & 45 & 101.12 & & & & \\
\hline & Yabancı Dil Öğrt. & 14 & 113.82 & & & & \\
\hline & Diğer & 14 & 108.96 & & & & \\
\hline \multirow{5}{*}{ ETSYÖ Genel } & Türkçe Öğrt. & 46 & 110.86 & \multirow{5}{*}{4} & \multirow{5}{*}{1.53} & \multirow{5}{*}{0.82} & \\
\hline & Türk Dili ve Ed. & 110 & 123.33 & & & & \\
\hline & Sınıf Öğrt. & 45 & 101.12 & & & & \\
\hline & Yabancı Dil Öğrt. & 14 & 113.82 & & & & \\
\hline & Diğer & 14 & 108.96 & & & & \\
\hline
\end{tabular}

Tablo 8'deki sonuçlara bakıldığında, Türkçe Öğretmenliği, Türk Dili ve Edebiyatı Öğretmenliği, Sınıf Öğretmenliği, Yabancı Dil Öğretmenliği, Psikolojik Danışma ve Rehberlik Öğretmenliği, Güzel Sanatlar Öğretmenliği, Beden Eğitimi Öğretmenliği, Sosyal Bilgiler Öğretmenliği ve Fen Bilgisi Öğretmenliği gibi farklı alanlardan mezun olmuş ve Yabancı Dil Olarak Türkçe Öğretimi alanında görev yapmakta olan öğretmenlerin eğitim teknolojisi standartlarına yönelik öz yeterlik algılarının ölçeğin geneli (Ki-Kare=1.53; $p>0.05$ ) ve tüm alt boyutlarında anlamlı ölçüde farklılaşmadığı görülmektedir. 
Eğitim Teknolojisi Standartlarına Yönelik Öz Yeterlikler ile Mesleki Deneyim Değişkeni Arasındaki ilişski

Türkçeyi yabancı dil olarak öğretenlerin eğitim teknolojisi standartlarına yönelik öz yeterlik algılarının mesleki deneyim değişkeni bağlamında anlamlı ölçüde farklılaşıp farklılaşmadığı Kruskal Wallis-H Testi ile araştırılmış, sonuçlar Tablo 9'da gösterilmiştir.

Tablo 8. ETSYÖ algılarının mesleki deneyim değişkenine göre farklılaşma durumu

\begin{tabular}{|c|c|c|c|c|c|c|c|}
\hline Alt Boyutlar & Mesleki Den. & $\mathrm{N}$ & Sira Ort. & sd & Ki-Kare & $p$ & Anlamlı Fark \\
\hline \multirow{6}{*}{$\begin{array}{l}\text { Öğrenmeyi } \\
\text { kolaylaştırma ve } \\
\text { yaratıcılığı teşvik } \\
\text { etme }\end{array}$} & $0-11$ ay & 36 & 124.63 & \multirow{6}{*}{5} & \multirow{6}{*}{4.59} & \multirow{6}{*}{0.47} & \\
\hline & $12-23$ ay & 32 & 130.39 & & & & \\
\hline & 24-35 ay & 53 & 110.20 & & & & \\
\hline & 3-5 yıl & 50 & 106.29 & & & & \\
\hline & 5-10 yıl & 31 & 119.76 & & & & \\
\hline & 10 yıldan fazla & 27 & 104.02 & & & & \\
\hline \multirow{6}{*}{$\begin{array}{l}\text { Öğrenme ortamları } \\
\text { ve değerlendirme } \\
\text { etkinlikleri } \\
\text { tasarımlama }\end{array}$} & 0-11 ay & 36 & 124.63 & \multirow{6}{*}{5} & \multirow{6}{*}{7.82} & \multirow{6}{*}{0.17} & \\
\hline & $12-23$ ay & 32 & 130.39 & & & & \\
\hline & 24-35 ay & 53 & 110.20 & & & & \\
\hline & 3-5 yıl & 50 & 106.29 & & & & \\
\hline & 5-10 yıl & 31 & 119.76 & & & & \\
\hline & 10 yıldan fazla & 27 & 104.02 & & & & \\
\hline \multirow{6}{*}{$\begin{array}{l}\text { Dijital çağın } \\
\text { çalışma ve } \\
\text { öğrenme } \\
\text { anlayışına öncülük } \\
\text { etme }\end{array}$} & 0-11 ay & 36 & 124.63 & \multirow{6}{*}{5} & \multirow{6}{*}{9.29} & \multirow{6}{*}{0.10} & \\
\hline & $12-23$ ay & 32 & 130.39 & & & & \\
\hline & 24-35 ay & 53 & 110.20 & & & & \\
\hline & 3-5 yıl & 50 & 106.29 & & & & \\
\hline & 5-10 yıl & 31 & 119.76 & & & & \\
\hline & 10 yıldan fazla & 27 & 104.02 & & & & \\
\hline \multirow{6}{*}{$\begin{array}{l}\text { Dijital } \\
\text { vatandaşlıkta } \\
\text { model olma }\end{array}$} & 0-11 ay & 36 & 124.63 & \multirow{6}{*}{5} & \multirow{6}{*}{3.46} & \multirow{6}{*}{0.63} & \\
\hline & $12-23$ ay & 32 & 130.39 & & & & \\
\hline & $24-35$ ay & 53 & 110.20 & & & & \\
\hline & 3-5 yıl & 50 & 106.29 & & & & \\
\hline & 5-10 yıl & 31 & 119.76 & & & & \\
\hline & 10 yıldan fazla & 27 & 104.02 & & & & \\
\hline \multirow{3}{*}{$\begin{array}{l}\text { Mesleki gelişim ve } \\
\text { liderlik } \\
\text { etkinliklerine } \\
\text { katılma }\end{array}$} & $0-11$ ay & 36 & 124.63 & \multirow{3}{*}{5} & \multirow{3}{*}{5.30} & \multirow{3}{*}{0.38} & \\
\hline & $12-23$ ay & 32 & 130.39 & & & & \\
\hline & 24-35 ay & 53 & 110.20 & & & & \\
\hline
\end{tabular}




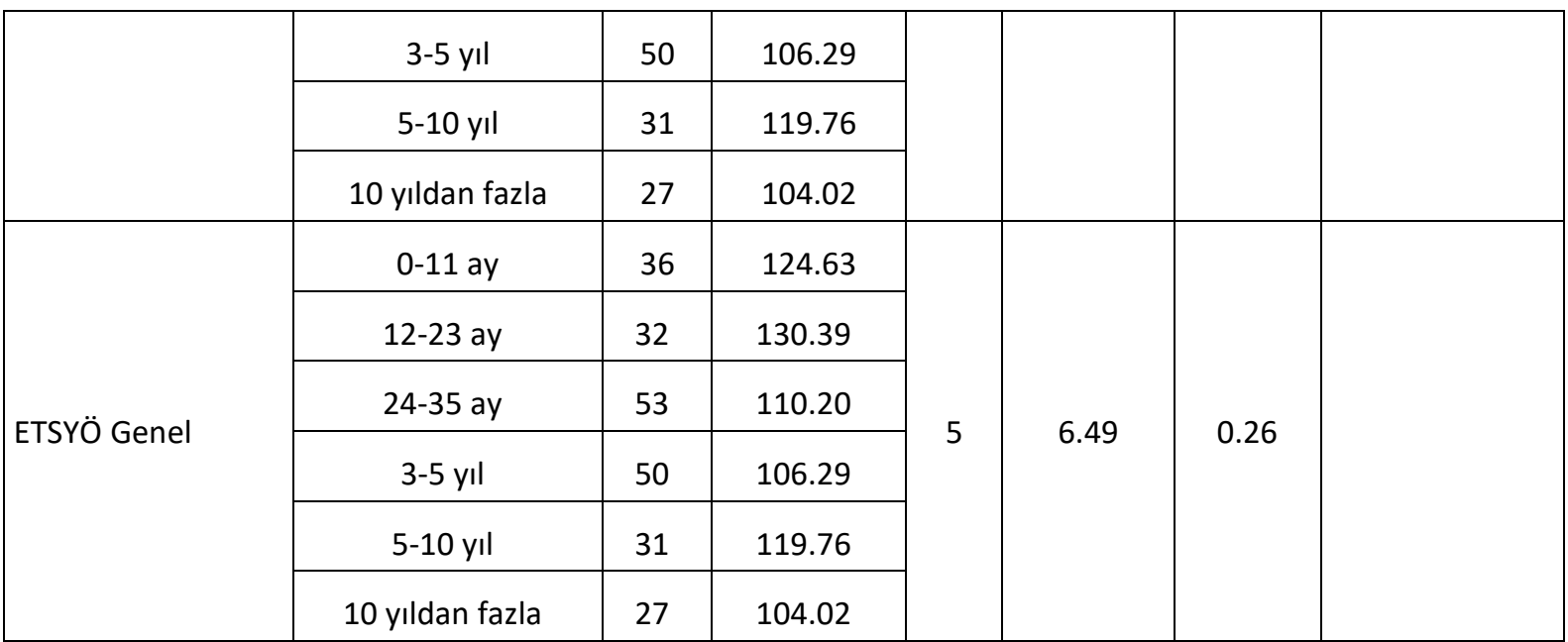

Tablo 9'daki sonuçlar, yabancı dil olarak Türkçe öğreticilerinin eğitim teknolojisi standartları öz yeterlik algıları ile mesleki deneyimleri arasında ölçeğin geneli (Ki-Kare=6.49; $p>0.05$ ) ve tüm alt boyutları bağlamında istatistiksel olarak anlamlı bir ilişkinin olmadığını ortaya koymuştur.

\section{Tartışma}

Eğitimde teknolojinin kullanım alanları artarken eğitimin öğrenici odaklı olması gerekliliği birçok eğitim anlayışının temelini oluşturmakta; ilgi, istek ve ihtiyaçları bağlamında nesiller değiş̧ikçe eğitim sistemleri, öğrenme ortamları, öğretim yöntem ve teknikleri de durmadan güncellenmektedir (Prensky, 2010). Bugün son derece hızlı gerçekleştiğini gözlemlediğimiz bu sürece öğretmenlerin de aynı çabuklukla uyum sağlamaları teknolojiden etkili şekilde faydalanabilmek ve eğitimi amaçlarına ulaştırabilmek adına son derece önemlidir (Chen ve Thieleman, 2008; Newby ve diğerleri, 2006; Watts Taffe ve Gwinn, 2007). Bu anlamda, Yabancı Dil Olarak Türkçe Öğretimi alanında öğretmenlerin eğitim teknolojisi standartlarına yönelik öz yeterlikleri, temel alan yeterlikleri kapsamında ele alınarak değerlendirilebilir.

Türkiye'nin farklı illerinde ve farklı öğretim kademelerinde yabancı dil olarak Türkçe öğreten 229 öğretmenin eğitim teknolojisi standartlarına yönelik öz yeterlik algılarının çeşitli değişkenler açısından incelendiği bu çalışmanın sonuçları, öğretmenlerin eğitim teknolojisi standartları öz yeterlik algılarının yüksek düzeyde olduğunu ortaya koymuştur. Öğretmenlerin eğitim teknolojisi standartları konusunda kendilerini en yeterli gördükleri boyutun "Mesleki gelişim ve liderlik etkinliklerine katılma" olduğu sonucuna ulaşılmıştır. Bu sonuçlar, yaşam boyu öğrenmeyi sürdürebilmek ve mesleki gelişimlerini desteklemek için öğretmenlerin bilgi ve iletişim teknolojileri alanındaki gelişmeleri takip ettiği, aynı zamanda yeniliğe ve gelişime açık oldukları şeklinde yorumlanabilir. Öğretmenlerin en az yeterli olduklarını düşündükleri alt boyutun ise "Dijital çağa uygun öğrenme ortamları ve değerlendirme etkinlikleri tasarımlama ve geliştirme" olduğu sonucuna ulaşılmıştır. Bu sonuçlar, Gündoğdu (2018)'nun üniversite hazırlık sınıflarında İngilizce öğreten okutmanların eğitim teknolojisi 
standartları öz yeterliklerini incelemek üzere yürüttüğü çalışmanın sonuçlarıyla uyuşmaktadır. Katılımcıların yabancı dil öğreticileri olduğu her iki çalışmada ulaşılan benzer sonuçlar, öğretmenlerin farklılaşan öğrenci profillerine göre öğrenme ortamları ve değerlendirme etkinlikleri tasarlama konusunda daha fazla yönlendirilmeye ihtiyaç duyduğunu göstermektedir. Farklı becerilerin işe koşulduğu yabancı dil öğretiminde, alımlayıcı ve üretken becerilerin edinimine yönelik teknoloji kullanımı konusunda uygulamalı hizmet içi eğitimlerle bu gereksinim karşılanabilir.

Yabancı dil olarak Türkçe öğretenlerin eğitim teknolojisi standartları açısından öz yeterlik düzeyleri yaş değişkenine göre incelendiğinde ölçeğin geneli ve "Dijital çağa uygun öğrenme ortamları ve değerlendirme etkinlikleri tasarımlama ve geliştirme”, "Dijital çağın çalışma ve öğrenme anlayışına öncülük etme" ve "Mesleki gelişim ve liderlik etkinliklerine katılma" alt boyutlarında 22-27 yaş grubundaki öğretmenlerin 36-42 ve 43 ve üzeri yaş gruplarındaki öğretmenlerden anlamlı ölçüde farklılaştığı görülmektedir. Ayrıca, "Dijital çağa uygun öğrenme ortamları ve değerlendirme etkinlikleri tasarımlama ve geliştirme" ve "Mesleki gelişim ve liderlik etkinliklerine katılma" alt boyutlarında 28-35 yaş grubundaki öğretmenler 43 ve üzeri yaş grubundaki öğretmenlerden anlamlı ölçüde farklılaşmaktadır. Genç öğretmenlerin lehine anlamlı farklıı̆̆ın ortaya çıktığı çalışmanın sonuçlarına göre yabancı dil olarak Türkçe öğreten genç yaştaki öğretmenlerin orta yaş ve üzeri öğretmenlerden eğitim teknolojisi standartları açısından öz yeterliklerinin daha yüksek olduğu söylenebilir. Usluel ve diğerleri (2007)'nin bilgi ve iletişim teknolojileri kullanıma yönelik öğretmen görüşlerini araştırdıkları çalışmanın sonuçları da benzer niteliktedir. Usluel ve diğerleri (2007), 20-29 yaş aralığındaki genç öğretmenlerin bilgi ve iletişim teknolojilerini öğrenme-öğretme ve değerlendirme süreçlerinde diğer yaş grubundaki öğretmenlere oranla daha fazla kullandıkları sonucuna ulaşmışlardır. Bu sonuçlar, dijital çağda öğretme ve öğrenme sürecinin önemli bir bileşeni olan teknolojiyi kullanma konusunda gençlerin daha yatkın oldukları şeklinde yorumlanabilir. Bu sebeple, üniversitelerin öğretmen yetiştirme programlarında teknolojinin eğitim amaçlı kullanımı ile ilgili ders içeriklerinin uygulamaya yönelik olarak düzenlenmesi ve ders sayısının artırılması önerilmektedir. Böylelikle, teknolojiyi kullanma konusunda üst düzey becerilere sahip olan gençlerin öğretme-öğrenme sürecinde teknolojiden en etkin şekilde yararlanabilmeleri sağlanabilir. Eğitim kurumlarında görev yapan orta ve ileri yaş grubundaki öğretmenlere de eğitimde teknoloji kullanımı konusunda hizmet içi eğitim verilmesinin uygun olacağı düşünülmektedir.

Öğretmenlerin eğitim teknolojisi standartları öz yeterlik düzeyleri cinsiyet değişkeni açısından incelendiğinde erkek ve kadın öğretmenler arasında anlamlı bir farklılaşma görülmemiştir. Sonuçlar, Özçiftçi ve Çakır (2015)'ın sınıf öğretmenleri, Ulucan ve Karabulut (2012)'un beden eğitimi öğretmen adayları, Çoklar ve Odabaşı (2010)'nın farklı bölümlerden öğretmen adayları, Şirin ve Duman (2013)'nın fizik bölümü öğretmen adayları, Makhabbat ve Çoklar (2018)'ın on üç farklı bölümden öğretmen 
Yabancı Dil Olarak Türkçe Öğretenlerin Eğitim Teknolojisi Standartları Öz-Yeterlik Algılarının İncelenmesi

adayları ile yaptığı çalışmaların sonuçları ile benzerlik göstermektedir. Bu sonuçlara göre erkek ve kadın öğretmenlerin eğitim teknolojilerinden aynı düzeyde faydalandıkları söylenebilir. Ancak çalışmada kadın katılımcıların sayısı erkek katıımcıların sayısının iki katından fazladır. Cinsiyet bağlamında sayıları birbirine yakın katılımcılarla yürütülecek yeni bir çalışmayla daha anlamlı sonuçlar elde edilebilir.

Çalışmanın sonuçları, ölçeğin geneli ve tüm alt boyutlarında, öğrenim durumu ve görev yapılan öğretim kademesinin öğretmenlerin öz yeterlik düzeylerinde anlamı ölçüde bir farklılaşmaya neden olmadığını göstermiştir. Şimşek ve Yazar (2017)'ın ortaokul ve liselerde görev yapan öğretmenlerle yürüttükleri çalışmada da benzer sonuçlar elde edilmiş, eğitim teknolojisi standartları öz yeterlikleri açısından öğretmenlerin öğrenim düzeyleri ve görev yaptıkları öğretim kademesine göre anlamlı ölçüde bir farklılaşma olmadığı gözlemlenmiştir. Ancak, mevcut çalışmada lisansüstü bir öğretim programından mezun olan katılımcıların toplam sayısının lisans programından mezun olanlara oranla oldukça az olması; ayrıca yükseköğretim kurumlarında görevli öğretmenlerin de sayıca azlığı nedeniyle benzer bir çalışma yürütülerek yabancı dil olarak Türkçe öğretenlerin eğitim teknolojisi standartları öz yeterlikleri öğrenim durumu ve öğretim kademesi değişkenleri açısından tekrar incelenebilir.

Mezuniyet alanları açısından değerlendirildiğinde, yabancı dil olarak Türkçe öğretenlerin eğitim teknolojisi standartlarına yönelik öz yeterliklerinin istatistiksel olarak anlamlı ölçüde farklılaşmadığı görülmüştür. Oskay (2017)'ın matematik, fen bilgisi ve sosyal bilgiler öğretmenleriyle yürüttüğü çalışmasında ulaştığı sonuçlar eğitim teknolojisi standartları öz yeterlikleri açısından branş değişkeninin anlamlı ölçüde bir farklılaşmaya neden olmadığını göstermiştir. Şimşek ve Yazar (2017) ve Ozan ve Taşgın (2017), aralarında bilgisayar ve öğretim teknolojileri alanından öğretmenlerin de olduğu farklı branştan öğretmenlerle yürüttükleri çalışmalarında bilgisayar ve öğretim teknolojileri alanındaki öğretmenlerin lehine anlamlı sonuçlar elde etmişlerdir. Benzer sonuçlara Çoklar ve Odabaşı (2010) tarafından farklı alanlarda öğrenim gören öğretmen adaylarıyla yürütülen çalışmada ulaşılmış, bilgisayar ve öğretim teknolojileri öğretmen adaylarının eğitim teknolojisi standartları öz yeterliklerinin diğer alanlarda öğrenim gören öğretmen adaylarından anlamlı ölçüde yüksek olduğu anlaşılmıştır. Öz yeterlikler bağlamındaki bu farklılaşmanın, bilgisayar ve öğretim teknolojileri eğitimi alanındaki öğretmen ve öğretmen adaylarının eğitim teknolojileri konusunda eğitim almış olmalarından kaynaklandığını söylemek mümkündür.

Çalışma kapsamında yabancı dil olarak Türkçe öğreticilerinin eğitim teknolojisi öz yeterlikleri mesleki deneyim bağlamında da incelenmiş ancak farklı öğretmenlik deneyimlerine sahip gruplar arasında istatistiksel olarak anlamlı ölçüde bir farklılaşma durumuna rastlanmamıştır. Bu sonuçlara göre, mesleki deneyimin eğitim teknolojisi standartları bağlamında Türkçeyi yabancı dil olarak öğretenlerin öz yeterlik düzeyleri üzerinde bir rolünün olmadığı söylenebilir. Ancak, Şimşek ve Yazar 
(2017)'ın ortaokul ve lise düzeyinde görev yapan ve farklı mesleki deneyime sahip öğretmenlerle yürüttükleri çalışmada mesleğinin ilk yıllarında olan öğretmenlerin eğitim teknolojisi standartları öz yeterliklerinin kendilerinden daha deneyimli öğretmenlere göre anlamlı ölçüde yüksek olduğu sonucuna ulaşmışlardır. Çalışmada elde edilen sonuçlar bağlamında, yabancılara Türkçe öğretenlerin teknolojik pedagojik alan bilgilerinin eğitim teknolojisi standartlarına yönelik öz yeterliklerine etkisi de araştırılabilir.

\section{Kaynaklar}

Adıgüzel, A. \& Yüksel, í. (2012). Öğretmenlerin Öğretim Teknolojileri Entegrasyon Becerilerinin Değerlendirilmesi: Yeni Pedagojik Yaklaşımlar için Nitel Bir Gereksinim Analizi. Sci. Math. Educ, 6(1), 265-286.

Akarsu, B. (2016). Hipotezlerin, Değişkenlerin ve Örneklemin Belirlenmesi. In M. Metin (Ed.), Kuramdan Uygulamaya Eğitimde Bilimsel Araştırma Yöntemleri (3 ed.). Ankara: Pegem Akademi.

Büyükaslan, A. (2007). Yabancı Dil Türkçenin Öğretilmesinde Yeni Yöntemler: Bilişim Uygulamaları, Çözüm Önerileri. Department D" etudes Turques Turcologue u-strasbourg, Strasbourg.

Cennamo, K. S., Ross, J. D. \& Ertmer, P. A. (2010). Technology Integration for Meaningful Classroom Use: A Standards-Based Approach. Australia: Wadsworth Cengage Learning.

Chen, H.-Y. (2013). Instructional Technology Applications in a Cooperative Learning Setting for an ESL Classroom.

Chen, I. \& Thieleman, J. (2008). Technology Application Competencies for K-12 Teachers. Hershey: Information Science Pub.

Christensen, L. B., Johnson, R. B. \& Turner, L. A. (2015). Araştırma Yöntemleri: Desen ve Analiz= Research Methods, Design, and Analysis (1 ed.). Ankara: Anı Yayıncılık.

Collins, A. \& Halverson, R. (2009). Rethinking Education in the Age of Technology: The Digital Revolution and Schooling in America. New York: Teachers College Press.

Çoklar, A. N. (2008). Öğretmen Adaylarının Eğitim Teknolojisi Standartları ile Ilgili Özyeterliklerinin Belirlenmesi. Yayımlanmamış Doktora Tezi. Eğitim Bilimleri Enstitüsü. Anadolu Üniversitesi. Eskişehir.

Çoklar, A. N. \& Odabaşı, H. F. (2010). Are Teacher Candidates able to Use Educational Technologies Effectively? A Case Study in Terms of Standards. Journal of Human Sciences, 7(2), 358-373.

Delgado, M. M. (2018). Teacher Self-Efficacy and Its Impact on the Integration of Instructional Technology in Classrooms. ProQuest LLC.

http://gateway.proquest.com/openurl?url_ver=Z39.88-

2004\&rft_val_fmt=info:ofi/fmt:kev:mtx:dissertation\&res_dat=xri:pqm\&rft_dat=xri:pqdiss:10743589

Available from EBSCOhost eric database.

Er, M. \& Er, N. F. (2013). Instructional Technology as a Tool in Creating Constructivist Classrooms.

Gündoğdu, G. Ç. (2018). The Educatıonal Technology Standards Competency of Instructors at Anadolu Unıversıty School of Foreign Languages. Paper presented at the 15th International Conference on Social Sciences, Leuven.

Ilgaz, H. \& Usluel, Y. (2011). Öğretim Sürecine BiT Entegrasyonu Açısından Öğretmen Yeterlikleri ve Mesleki Gelişim. Journal of Educational Sciences \& Practices, 10(19).

ISTE. (2008). ISTE National Educational Technology Standards for Teachers. Retrieved from http://www.iste.org/standards/standards-for-teachers/nets-for-teachers-2008

ISTE. (2017). ISTE Standards for Teachers. Retrieved from https://www.iste.org/standards/standards/forteachers-refresh-2016-Ip. 
Kadijevich, D. \& Haapasalo, L. (2008). Factors that Influence Student Teacher's Interest to Achieve Educational Technology Standards. Computers and Education, 50(1), 262-270.

Karasar, N. (2014). Bilimsel Araştırma Yöntemi: Kavramlar, ilkeler, Teknikler (27 ed.). Ankara: Nobel Yayın Dağıtım.

Makhabbat, A. \& Çoklar, A. N. (2018). Öğretmen Adaylarının Eğitim Teknolojisi Standartlarına Yönelik Özyeterliklerinin Belirlenmesi Uluslararası Eğitim Bilimleri Dergisi, 5(15), 141-153.

Mishra, P. \& Koehler, M. J. (2006). Technological Pedagogical Content Knowledge: A Framework for Teacher Knowledge. Teachers College Record, 108(6), 1017-1054.

Newby, T. J., Stepich, D. A., Lehman, J. D. \& Russel, J. D. (2006). Educational Technology for Teaching and Learning (3 ed.). Upper Saddle River, N. J.: Pearson/Merrill Prentice Hall.

Orhan-Karsak, H. G. (2017). Investigation of Teacher Candidates' Opinions about Instructional Technologies and Material Usage. Journal of Education and Training Studies, 5(5), 204-216.

Oskay, Ö. Ö. (2017). An Investigation of Teachers' Self Efficacy Beliefs Concerning Educational Technology Standards and Technological Pedagogical Content Knowledge. Eurasia Journal of Mathematics, Science and Technology Education, 13(8), 4739-4752.

Ozan, C. \& Taşgın, A. (2017). Öğretmen Adaylarının Eğitim Teknolojisi Standartlarına Yönelik Öz Yeterliklerinin İncelenmesi. Eğitim Teknolojisi Kuram ve Uygulama, 7(2), 236-253.

Özçiftçi, M. \& Çakır, R. (2015). Öğretmenlerin Yaşam Boyu Öğrenme Eğilimleri ve Eğitim Teknolojisi Standartları Özyeterliklerinin İncelenmesi. Eğitim Teknolojisi Kuram ve Uygulama, 5(1).

Özpinar, I., Yenmez, A. A. \& Gökçe, S. (2016). An Application of Flipped Classroom Method in the Instructional Technologies and Material Development Course. Journal of Education and Training Studies, 4(12), 213226.

Prensky, M. (2010). Teaching Digital Natives: Partnering for Real Learning. Thousand Oaks, California: Corwin Press.

Roblyer, M. D. \& Doering, A. H. (2010). Integrating Educational Technology into Teaching (5 ed.). Boston: Allyn and Bacon.

Seferoğlu, S. S. (2009). Yeterlikler, Standartlar ve Bilişim Teknolojilerindeki Gelişmeler Işığında Öğretmenlerin Sürekli Mesleki Eğitimi. Eğitimde Yansımalar IX: Türkiye'nin Öğretmen Yetiştirme Çıkmazı Ulusal Sempozyumu, 204-217.

Shaw, C. M. \& Tan, S. A. (2015). Integration of Mobile Technology in Educational Materials Improves Participation: Creation of a Novel Smartphone Application for Resident Education. Journal of surgical education, 72(4), 670-673.

Smaldino, S. E., Lowther, D. L. \& Russell, J. D. (2014). Instructional Technology and Media for Learning (10 ed.). Edinburg: Pearson.

Şahin, B. (2014). Metodoloji. In A. Tanrıöğen (Ed.), Bilimsel Araştırma Yöntemleri. Ankara: Anı Yayıncılık.

Şimsek, Ö. \& Yazar, T. (2016). Education Technology Standards Self-Efficacy (ETSSE) Scale: A Validity and Reliability Study Eurasian Journal of Educational Research, 16(63).

Şimşek, Ö. \& Yazar, T. (2017). Öğretmenlerin Eğitim Teknolojisi Standartlarına Yönelik Özyeterliklerinin İncelenmesi. Pegem Eğitim ve Öğretim Dergisi, 7(1), 23-54.

Şimşek, Ö. \& Yazar, T. (2018). Öğretmen Adaylarının Eğitimde Teknoloji Entegrasyon Öz-Yeterliklerinin Incelenmesi: Türkiye Örneği. Electronic Journal of Social Sciences, 17(66).

Şirin, E. F. \& Duman, S. (2013). An Investigation of Educational Technology Standarts of Physical Education Candidate Teachers in Terms of Several Variables. Journal of Human Sciences, 10(1), 1298-1313.

Ulucan, H. \& Karabulut, E. O. (2012). Beden Eğitimi Öğretmen Adaylarının Eğitim Teknolojisi Standartları ile ilgili Özyeterliklerinin İncelenmesi. Selçuk Üniversitesi Beden Eğitimi ve Spor Bilim Dergisi, 14(2), 243-248. 
Ural, A. \& Kılıç, İ. (2011). Bilimsel Araştırma Süreci ve SPSS ile Veri Analizi (3 ed.). Ankara: Detay Yayıncılık.

Usluel, Y. K., Mumcu, F. K. \& Demiraslan, Y. (2007). Öğrenme-Öğretme Sürecinde Bilgi ve İletişim Teknolojileri: Öğretmenlerin Entegrasyon Süreci ve Engelleriyle İlgili Görüşleri. Hacettepe Üniversitesi Eğitim Fakültesi Dergisi, 32(32).

Watts Taffe, S. \& Gwinn, C. B. (2007). Integrating Literacy and Technology: Effective Practice for Grades K-6. New York: Guilford Press.

Yılmaz, H. (2018). Fen Bilgisi Öğretmen Adaylarının Eğitim Teknolojisi Standartlarına Yönelik Mesleki Eğitimlerinin Yeterliğine Ilişkin Görüşleri. (Yayımlanmamış Yüksek Lisans Tezi), Kastamonu Üniversitesi, Kastamonu.

Younie, S. \& Leask, M. (2013). Teaching with Technologies: The Essential Guide. England: Open University Press.

\section{Extended Abstract Introduction}

Technology has been an essential part of education for years. New concepts such as technology assisted learning environments, digital materials, mobile learning and web tools have become increasingly important. However, it should be noted that technology cannot be replaced by the teacher. Instead, it is possible to talk about the differentiated roles of students and teachers in the light of technological innovations (Cennamo, Ross ve Ertmer, 2010, ss. 12-13). In order to understand the changing roles and responsibilities of students and teachers, who are the most important actors of education, teachers should be aware of the characteristics of 21st century students.

As it is in every field, it is a necessity in the education process to update teachers' competencies considering the characteristics of our age and the interests and needs of our students. In addition to being an expert in the use of modern technologies, a good teacher should be able to adapt these technologies in teaching and learning environments.

Technological practices play a vital role in search of solutions to important problems in teaching of foreign languages. Non-native teachers of the target language can take advantage of technology to help students communicate with native speakers and design authentic learning environments. Multimedia tools such as sound, image, video, graphics and animation activate different senses, and provide better learning experiences as a result.

As interest in the use of technology in education has increased, a set of guidelines has been developed for the effective use of technology in education worldwide. The International Society for Technology in Education (ISTE) is a roadmap for educators to improve their self-efficacy regarding educational technology standards. In this study, Turkish language teachers' self-efficacies regarding educational technology standards were examined in terms of age, gender, level of education, teaching level, department and professional experience.

Method

The survey model was used in the study, and the data obtained from Educational Technology Standards Self-Efficacy Scale were analyzed quantitatively. The participants consisted of 229 teachers of Turkish as a foreign language who are teaching in primary and secondary schools and higher education institutions in Turkey and abroad. The research questions addressed in the study were as follows:

1. What is the distribution of self-efficacy scores of the teachers who teach Turkish as a foreign language in the educational technology standards scale and in the sub-dimensions of the scale?

2. Do the self-efficacies of the teachers who teach Turkish as a foreign language differ significantly in terms of age?

3. Do the self-efficacies of the teachers who teach Turkish as a foreign language differ significantly in terms of gender?

4. Do the self-efficacies of the teachers who teach Turkish as a foreign language differ significantly in terms of level of education?

5. Do the self-efficacies of the teachers who teach Turkish as a foreign language differ significantly in terms of teaching level?

6. Do the self-efficacies of the teachers who teach Turkish as a foreign language differ significantly in terms of department?

7. Do the self-efficacies of the teachers who teach Turkish as a foreign language differ significantly in terms of professional experience?

\section{Results and Discussion}

The results of the study revealed that teachers' self-efficacy levels regarding educational technology standards were high $(\bar{X}=3,85)$. In terms of sub-dimensions, the highest average score was taken from the sub- 
dimension "Participating in professional development and leadership activities" and the lowest average score was taken from the sub-dimension "Designing and developing learning environments and assessment activities that correspond to the requirements of the digital era". In terms of age variable, it was found that young teachers had higher self-efficacies compared to teachers of middle age and above. However, there were no significant differences between the groups in terms of gender, so it can be stated that male and female teachers benefit from technology equally in education. Similarly, no significant differences were found in teachers' self-efficacies regarding their level of education and teaching level. However, the total number of participants who have a graduate degree was relatively low compared to those graduated from undergraduate programs; and the teachers working in higher education institutions were relatively few, so these results needs to be confirmed with further research. In terms of department and professional experience variable, teachers' self-efficacies regarding educational technology standards did not differ significantly.

Based on the results of the study, it can be suggested that the effects of technological pedagogical content knowledge of Turkish language teachers on their self-efficacy regarding educational technology standards can be investigated. While no significant difference was observed in teachers' self-efficacies regarding educational technology standards in terms of their professional experience, there was a significant difference in favor of the younger ones with regard to the age variable. Considering these results, it would be appropriate to provide in-service training on the use of technology in education for teachers of middle age and above who work in educational institutions. As it is in all fields, technology has an important place in education as well. For this reason, it is recommended that the content of the educational technology courses in teacher training programs of universities should be arranged to promote practical use of technology in classrooms and the number of courses should be increased, as well. 